\title{
Intelligent Monitoring Using Hazard Identification Technique and Multi-Sensor Data Fusion for Crude Distillation Column
}

\author{
Peter Omoarebun ${ }^{1}$, David Sanders ${ }^{1}$, Favour Ikwan ${ }^{1}$, Mohamed Hassan ${ }^{2}$ \\ Jake Piner ${ }^{4}$ and Amjad Shah ${ }^{3}$
}

\author{
Malik Haddad ${ }^{1}$, Mohamad Thabet $^{3}$,
}

\begin{abstract}
Hazard assessment techniques and multi-sensor fusion are used for intelligent systematic monitoring. Firstly, a hazard identification technique is considered using failure mode and effect analysis and advantages of using a combined hazard technique is discussed. Data sources are identified considering component failures and some sensors associated with potential failure. Possible consequences in a hazardous situation are identified using failure mode and effect analysis to choose suitable safety measures. Failure mode and effect analysis is systematically considers how sequences of events can lead to accidents by looking at components and faults recorded by sensors and anomalies. Data were presented based on their threat levels using a traffic light color code system. Refineries use sensors to observe the process of crude refining and the monitoring system uses real-time data to access information provided by sensors. Understanding hazard assessments, sensor multi-fusion and sensor pattern recognition in a distillation column could help to identify trends, flag major regions of growing malfunction, model risk threat of a crude distillation column and help to systematically make decisions. The decisions could improve design regulations, eliminate anomalies, improve monitoring and reduce threat levels.
\end{abstract}

Keywords: Hazard, Sensors, Crude, Distillation, Sensor, Intelligent, Monitoring.

\section{Introduction}

In gas and oil industries, sensors are used to constantly monitor situations to avoid a likelihood of disasters.

A refinery operates in a closed uniform environment that contains some mixture of varying pressure and temperature conditions. This could result in catastrophic events if not monitored prudently. The monitoring of numerous sensors in a refinery could be time-consuming and labour intensive even with periodic maintenance, faults might not be detected during maintenance [1-3].

Assessing the safety of a complex refinery involves the handling of historic data, fuzzy risk parameters and incomplete models of risk. A quantitative or qualitative approach to safety could be used but to achieve that assessment, it may be possible to categorize risk elements that might cause events leading to systems failure [4].

Analysing risk involves a logical reasoning of cause and effect [5]. Most models for analyzing risk use quantitative approaches, that is a mathematical approach to quantifying risk in terms of consequences and their likelihood of occurring [6]. Risk evaluation is important in studying risk of hazards. Durrant in [7] emphasized a need for machine learning and data mining techniques to extract knowledge / information from gas and oil industry data. Data mining applications have been described in [8-11].

Detecting faults within refinery sensors is important because:

- It helps with making decisions about whether production processes should be halted before situations become critical, even if significant information may be missing.

- It can help operators to decide on maintenance needs.

- Detecting repeated similar faults could provide information about sensor quality and could lead to improved design. 


\section{Hazard Identification Techniques}

Some commonly used procedures for identifying hazards, and for the evaluation and analysis of risk are described here.

\subsection{Failure Mode Effect and Analysis}

Failure Mode Effect and Analysis (FMEA) is an effective systematic technique for accessing and organizing possible failures in a design or process by itemizing a process and then assigning a risk priority to each item (Table 1). FMEA has been used for reliability and safety assessment of system components [12]. It prioritizes failure against severity, detectability and occurrences (Consequences):

- Severity - How serious is the consequence of failure.

- Detectability - How difficult is it to detect failure.

- Occurrences - How often a failure occurs.

In the work described in this paper, FMEA was used with other safety techniques.

Table 1. Failure Mode Effect and Analysis (FMEA)

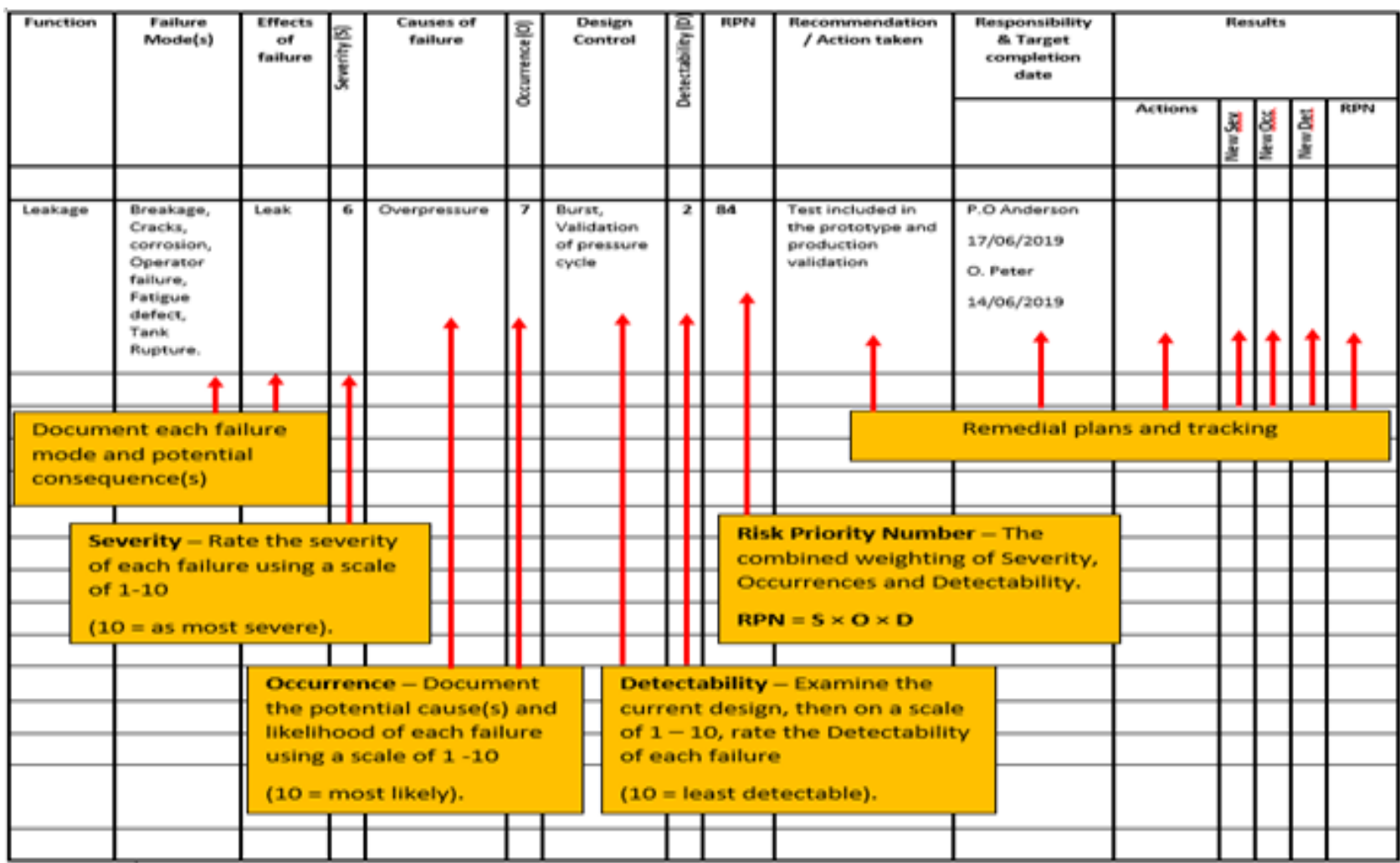

\subsection{Fault Tree Analysis}

A Fault Tree is a diagram of the interrelationships between causes or modes of failure that could precede undesired events. Fault Tree Analysis (FTA) identifies risk and can determine probability or the level of risk that an undesirable event might occur. That analysis involves sequencing failure interrelationships [13].

FTA was applied to a section of a crude distillation column and the basic events were identified in Fig. 1. Fig. 1. shows the causes that led to the event as shown. 


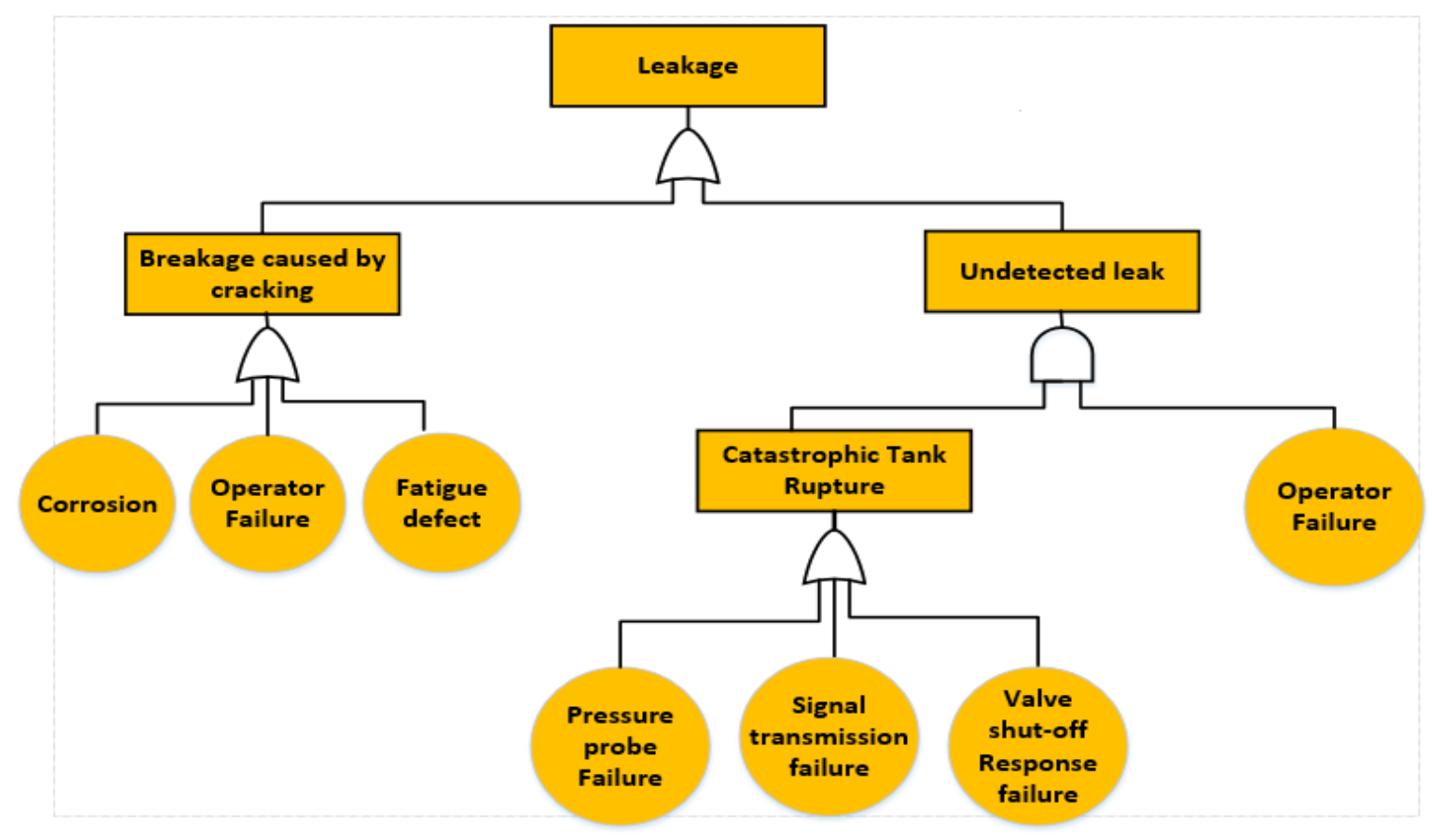

Fig. 1. Fault Tree Analysis of leak in a pipeline.

\subsection{Event Tree Analysis}

Event Tree Analysis (ETA) is technique for assessing safety, especially after an abnormal function or accident. ETA is an inductive reasoning process. The process begins with some initiating-event and produces an illustration to analyze the effect of a set of undesirable events [14].

ETA establishes the frequency or probability of an accident. Suitable safeguarding measures can then be put in place to prevent or at least to mitigate escalation following an undesired event [14]. An initiating-event is created depending on some initiating conditions (no / yes, false / true, failure / success) and then the consequences of the event are traced within branches of the ETA [15].

\section{Using Combined Hazard Techniques}

Bow-tie analysis can be helpful for combining hazard analysis techniques and identifying risk from both techniques.

\subsection{Bowtie Analysis}

Bowtie analysis is a probabilistic approach based on consequences and causes of undesirable events [16]. It is a logical method that establishes relationships between cause and effect that can be used to mitigate, control and prevent accidents [15].

Bowtie analysis has been used to assess risk, safety and reliability of complicated systems. Bow-tie is a risk approach that graphically displays the relationships between hazardous events; its causes and consequences and the risk control barriers in place to stop the accident sequence (Fig. 2). 


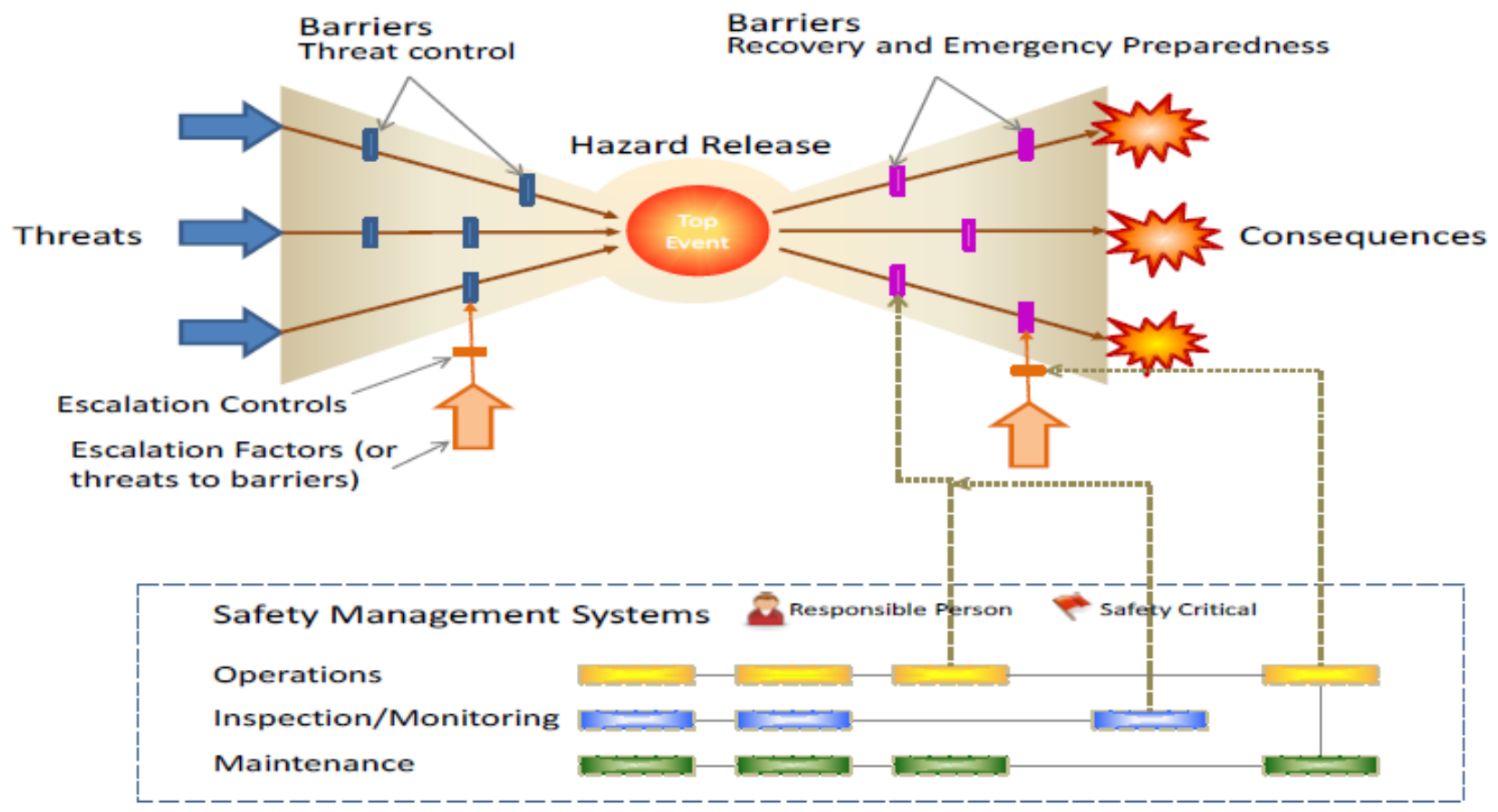

Fig. 2. Bow-tie analysis explaining the relationship between barriers, threat and consequences

\subsection{Fault Tree and Event Tree Analysis}

Investigating failure modes using event tree (ETA) and fault tree (FTA) has been an effective way of identifying failure. These might include human error or concurrent component failures. The combination allowed for an analysis of cause and effect that can lead to technical breakdown or accident.

The use of ETA and FTA in the new work described in this paper provided a thorough analysis of potential hazards and their potential causes. That helped improve overall performance. FTA and ETA are complimentary (and they have often been used together) but they focus on opposite sides of an undesired event. Bow-tie analysis can link both methods together and the new combination of FTA and ETA can help to determine a single undesired event that could lead to catastrophe. In reality though, multiple causes can initially lead to different events, with each of them expanding into multiple consequences. FTA focuses on preventive measures and ETA on mitigation measures [15] as shown in Fig. 3.

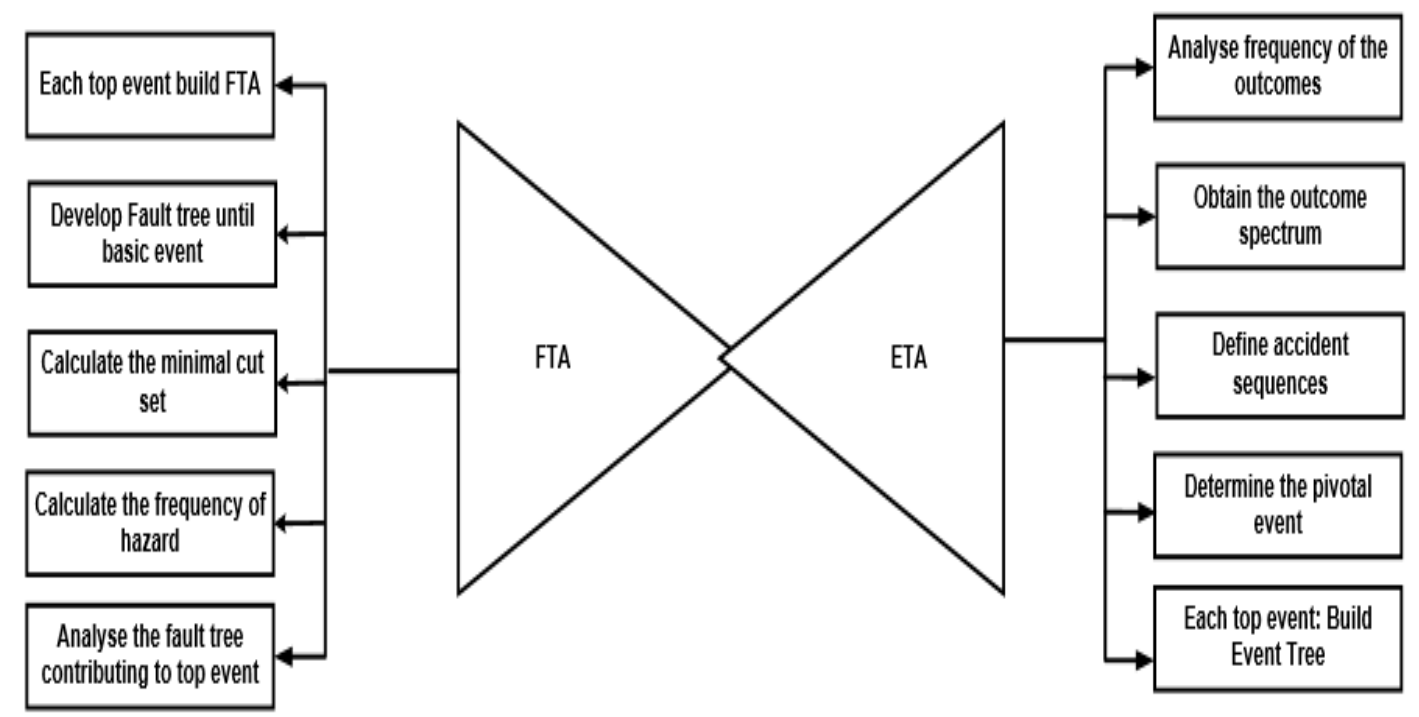

Fig. 3. Combined hazard techniques using FTA and ETA. 
Bow-tie Analysis involved combining both deductive and inductive techniques based on an ETA and FTA.

Table 1, shows a matrix table of 50 years of crude distillation tower failure, with failure modes identified, and effects identified, with possible sensor/fault detection listed. A hazard technique using FMEA was applied to the data using a colour coding system from a scale of $1-10$ to identify the occurrences, detectability and severity to calculate a risk priority number. Red represented a more catastrophic state, amber represented a critical operational margin and green represented an optimal operational condition. A Risk Priority Number (RPN) formula was used.

$$
\mathrm{RPN}=\mathrm{O} \times \mathrm{D} \times \mathrm{S}
$$

The higher the RPN number, the higher the risk value of the system (components). The lower the RPN the lower the likelihood of risk. Data in Table 2 shows that Abnormal operation incidents (Start-up, shutdown, commissioning) represented the highest failure mode in a crude distillation column, while heat integration issues accounted for the lowest number of modes of failure for the system.

Table 2. Crude distillation tower risk matrix.

\begin{tabular}{|c|c|c|c|c|c|c|c|c|}
\hline Function & $\begin{array}{l}\text { Failure } \\
\text { Mode }\end{array}$ & Effect Causes & $\begin{array}{l}\text { Possible } \\
\text { Control } \\
\text { /Fault } \\
\text { Detection } \\
\text { Sensors. }\end{array}$ & $\mathrm{O}$ & D & $S$ & RPN & Action \\
\hline \multirow{6}{*}{ 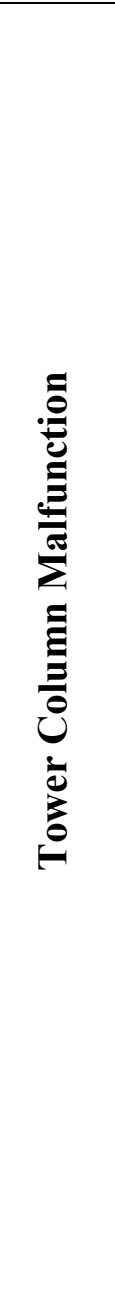 } & Tower base & $\begin{array}{l}\text { High and low } \\
\text { base level, } \\
\text { Vapour } \\
\text { Misdistribution. }\end{array}$ & $\begin{array}{l}\text { Through } \\
\text { changes in } \\
\text { temperature } \\
\text { and } \\
\text { pressure. }\end{array}$ & 8 & 4 & 6 & 192 & $\begin{array}{l}\text { Prevent } \\
\text { excessive } \\
\text { tower base } \\
\text { level, good } \\
\text { sump design. }\end{array}$ \\
\hline & $\begin{array}{l}\text { Re-boiler } \\
\text { return }\end{array}$ & $\begin{array}{l}\text { Faulty level } \\
\text { measurement } \\
\text { or control, } \\
\text { Excess re-boiler } \\
\text { pressure drop. }\end{array}$ & $\begin{array}{l}\text { Through } \\
\text { change in } \\
\text { level sensing } \\
\text { and change } \\
\text { in pressure. }\end{array}$ & 5 & 3 & 6 & 90 & $\begin{array}{l}\text { Have a } \\
\text { frequent } \\
\text { assessment } \\
\text { checks, have } \\
\text { a level sensor } \\
\text { in place. }\end{array}$ \\
\hline & $\begin{array}{l}\text { Damage to } \\
\text { internal } \\
\text { tower }\end{array}$ & $\begin{array}{l}\text { Insufficient } \\
\text { mechanical } \\
\text { resistance, } \\
\text { water induced } \\
\text { pressure, high . }\end{array}$ & $\begin{array}{l}\text { Abnormal } \\
\text { operation, } \\
\text { change in } \\
\text { Temp\& } \\
\text { Press. } \\
\text { Readings. }\end{array}$ & 8 & 2 & 7 & 112 & $\begin{array}{l}\text { The key } \\
\text { prevention is } \\
\text { to keep the } \\
\text { water out. }\end{array}$ \\
\hline & $\begin{array}{l}\text { Water } \\
\text { induced } \\
\text { surge }\end{array}$ & $\begin{array}{l}\text { Undrained } \\
\text { stripping steam } \\
\text { lines, water in } \\
\text { feed/slop. }\end{array}$ & $\begin{array}{l}\text { Change in } \\
\text { temperature } \\
\text { and } \\
\text { pressure. }\end{array}$ & 6 & 3 & 8 & 144 & $\begin{array}{l}\text { Monitor } \\
\text { water in-let, } \\
\text { avoid } \\
\text { abnormal } \\
\text { operation }\end{array}$ \\
\hline & $\begin{array}{l}\text { Abnormal } \\
\text { operation } \\
\text { incidents } \\
\text { (Start-up, } \\
\text { shutdown, } \\
\text { commission } \\
\text { ing) }\end{array}$ & $\begin{array}{l}\text { Backflow, water } \\
\text { removal from } \\
\text { refinery } \\
\text { fractionators, } \\
\text { leads to } \\
\text { plugging/coking } \\
\text { and internal } \\
\text { damage. }\end{array}$ & $\begin{array}{l}\text { Flow } \\
\text { transmitter } \\
\text { and Level } \\
\text { sensing. }\end{array}$ & 8 & 4 & 8 & 364 & $\begin{array}{l}\text { Implement } \\
\text { hazard } \\
\text { techniques } \\
\text { HAZOP and } \\
\text { conduct } \\
\text { frequent } \\
\text { safety audits. }\end{array}$ \\
\hline & $\begin{array}{l}\text { Assembly } \\
\text { mishaps }\end{array}$ & $\begin{array}{l}\text { Incorrect } \\
\text { assembly or } \\
\text { packing. }\end{array}$ & $\begin{array}{l}\text { X-ray, } \\
\text { acoustics } \\
\text { sensors. }\end{array}$ & 7 & 5 & 7 & 196 & $\begin{array}{l}\text { Introduce / } \\
\text { initiate a } \\
\text { systematic } \\
\text { and thorough } \\
\text { tower } \\
\text { process } \\
\text { inspection } \\
\text { programs. }\end{array}$ \\
\hline
\end{tabular}




\begin{tabular}{|c|c|c|c|c|c|c|c|c|}
\hline \multirow{8}{*}{ 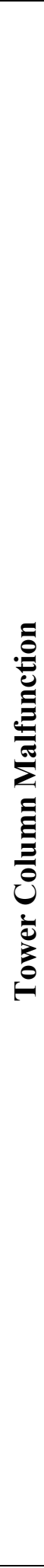 } & $\begin{array}{l}\text { Packing } \\
\text { liquid } \\
\text { distributors }\end{array}$ & $\begin{array}{l}\text { Plugging and } \\
\text { overflow, poor } \\
\text { irrigation } \\
\text { quality, feed } \\
\text { entry problems. }\end{array}$ & $\begin{array}{l}\text { Level sensor, } \\
\text { Flow } \\
\text { transmitter. }\end{array}$ & 6 & 4 & 7 & 168 & \\
\hline & $\begin{array}{l}\text { Inter- } \\
\text { mediate } \\
\text { draws } \\
\text { (includes } \\
\text { chimney } \\
\text { trays) }\end{array}$ & $\begin{array}{l}\text { Leakage at the } \\
\text { draw, } \\
\text { restriction or } \\
\text { vapour choke of } \\
\text { draw line, } \\
\text { plugging } \\
\text { /coking, level } \\
\text { measurement, } \\
\text { vapour } \\
\text { impingement. }\end{array}$ & $\begin{array}{l}\text { Level sensor, } \\
\text { leak } \\
\text { detector. }\end{array}$ & 5 & 3 & 8 & 120 & $\begin{array}{l}\text { Review the } \\
\text { design of the } \\
\text { intermediate } \\
\text { draws, } \\
\text { Reduce } \\
\text { pushing of } \\
\text { towers to } \\
\text { maximum } \\
\text { capacities. }\end{array}$ \\
\hline & Re-boilers & $\begin{array}{l}\text { Excess change } \\
\text { in pressure in } \\
\text { kettle circuit, } \\
\text { Forced } \\
\text { circulation of } \\
\text { re-boilers. }\end{array}$ & $\begin{array}{l}\text { Pressure } \\
\text { sensor. }\end{array}$ & 5 & 4 & 7 & 140 & $\begin{array}{l}\text { Reduction } \\
\text { and } \\
\text { evaluation of } \\
\text { troublesome } \\
\text { re-boiler } \\
\text { types. }\end{array}$ \\
\hline & $\begin{array}{l}\text { Chemical } \\
\text { explosions }\end{array}$ & $\begin{array}{l}\text { Decompositions } \\
\text { of compound, } \\
\text { chemical } \\
\text { release, violent } \\
\text { reactions. }\end{array}$ & $\begin{array}{l}\text { Pressure } \\
\text { and } \\
\text { temperature } \\
\text { sensor. }\end{array}$ & 4 & 9 & 8 & 288 & $\begin{array}{l}\text { Reduce } \\
\text { excessive } \\
\text { temperature } \\
\text { and catalysis } \\
\text { of metal or } \\
\text { catalyst by air } \\
\text { leaks. }\end{array}$ \\
\hline & Leaks & $\begin{array}{l}\text { Heat } \\
\text { exchangers (re- } \\
\text { boiler tube, } \\
\text { preheater, } \\
\text { pump around } \\
\text { exchanger } \\
\text { condenser), } \\
\text { Column } \\
\text { chemicals to } \\
\text { atmosphere. }\end{array}$ & $\begin{array}{l}\text { Temp' } \\
\text { sensor. }\end{array}$ & 3 & 7 & 3 & 63 & \\
\hline & Simulations & $\begin{array}{l}\text { Poor VLE } \\
\text { predictions. }\end{array}$ & $\begin{array}{l}\text { Pressure } \\
\text { sensor. }\end{array}$ & 3 & 6 & 5 & 90 & $\begin{array}{l}\text { Understandin } \\
\text { g and having } \\
\text { a good VLE } \\
\text { prediction. }\end{array}$ \\
\hline & $\begin{array}{l}\text { Condensers } \\
\text { issues }\end{array}$ & $\begin{array}{l}\text { Inadequate } \\
\text { venting, } \\
\text { inadequate } \\
\text { condensate } \\
\text { removal, } \\
\text { flooding/ } \\
\text { entrainment in } \\
\text { partial } \\
\text { condenser. }\end{array}$ & $\begin{array}{l}\text { Pressure } \\
\text { sensor. }\end{array}$ & 3 & 2 & 6 & 36 & $\begin{array}{l}\text { Ensure the } \\
\text { vent is clean, } \\
\text { well vented } \\
\text { and draining. }\end{array}$ \\
\hline & $\begin{array}{l}\text { Heat } \\
\text { integration } \\
\text { issues }\end{array}$ & $\begin{array}{l}\text { High degree } \\
\text { heat integration } \\
\text { practiced } \\
\text { (multi-feed } \\
\text { arrangements), } \\
\text { preheaters, } \\
\text { inter-reboilers } \\
\text { and recycle } \\
\text { loops. }\end{array}$ & $\begin{array}{l}\text { Temp' } \\
\text { sensor. }\end{array}$ & 1 & 3 & 6 & 18 & $\begin{array}{l}\text { Bypass tower } \\
\text { or preheater. }\end{array}$ \\
\hline
\end{tabular}


Sensors are devices designed to receive prompt and respond with an electrical signal and they can be modified and amplified by electronic devices.

Sensors are energy converters and some quantities that could be sensed include: motion, displacement, force, strain, pressure, flow, sound, moisture, light intensity, radiation, temperature, chemical presence velocity and acceleration.

White [21] defined multi-sensor fusion as a multifaceted and multi-level process to automatically detect, associate, correlate, estimate, and combine data (or possibly information) from numerous sources. Klein [18] generalized the definition, saying data could be from multiple sources or a single source.

\subsection{Sensor Pattern Recognition}

Research described in this paper investigated using Artificial Intelligence (AI) techniques for sensor fusion, especially pattern recognition. Pattern recognition depended mainly on trend data and data acquired from sensor's information. Combinations of data from multiple-sensors were considered. Pattern recognition and AI techniques can convert large amounts of real time data into smaller pieces of information. That can allow complete system analysis and clustering methods and to be used.

The new proposed strategy is shown in Fig. 4. It aims to combine both the potential failure mode of a system with various sensor faults, and a scoring technique to analyze and identify systemic risk. The goal was to improve accuracy and reliability.

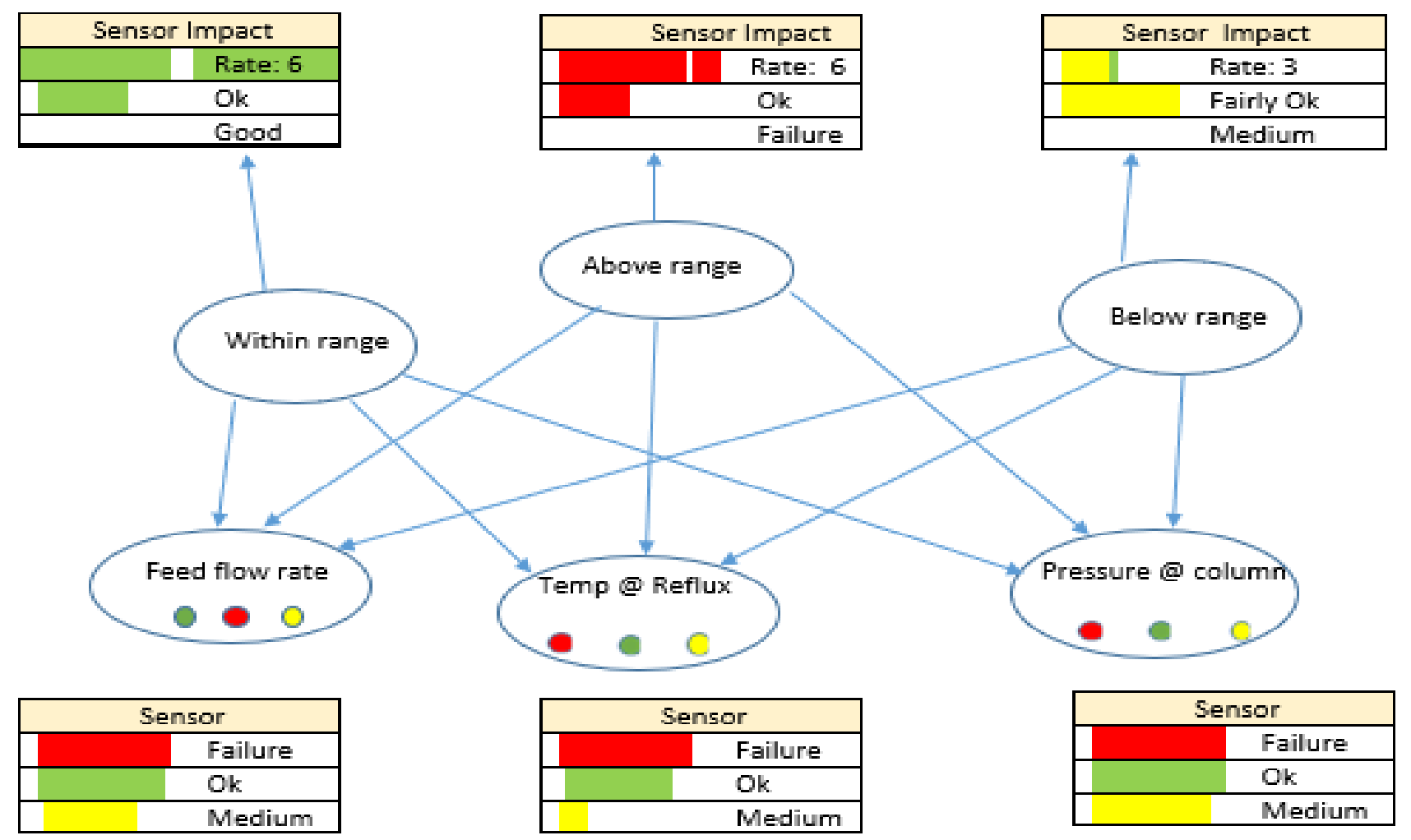

Fig. 4. Sensor pattern recognition and failure mode identified.

\section{$5 \quad$ Machine Learning Using Data Fusion}

Sensor fusion was used within machine learning to build a prototype intelligent monitoring system. The combination of multiple sensors could establish a pattern that could help create machine learning to find patterns in existing data. It used a model that recognized patterns in new data (Fig. 5). 


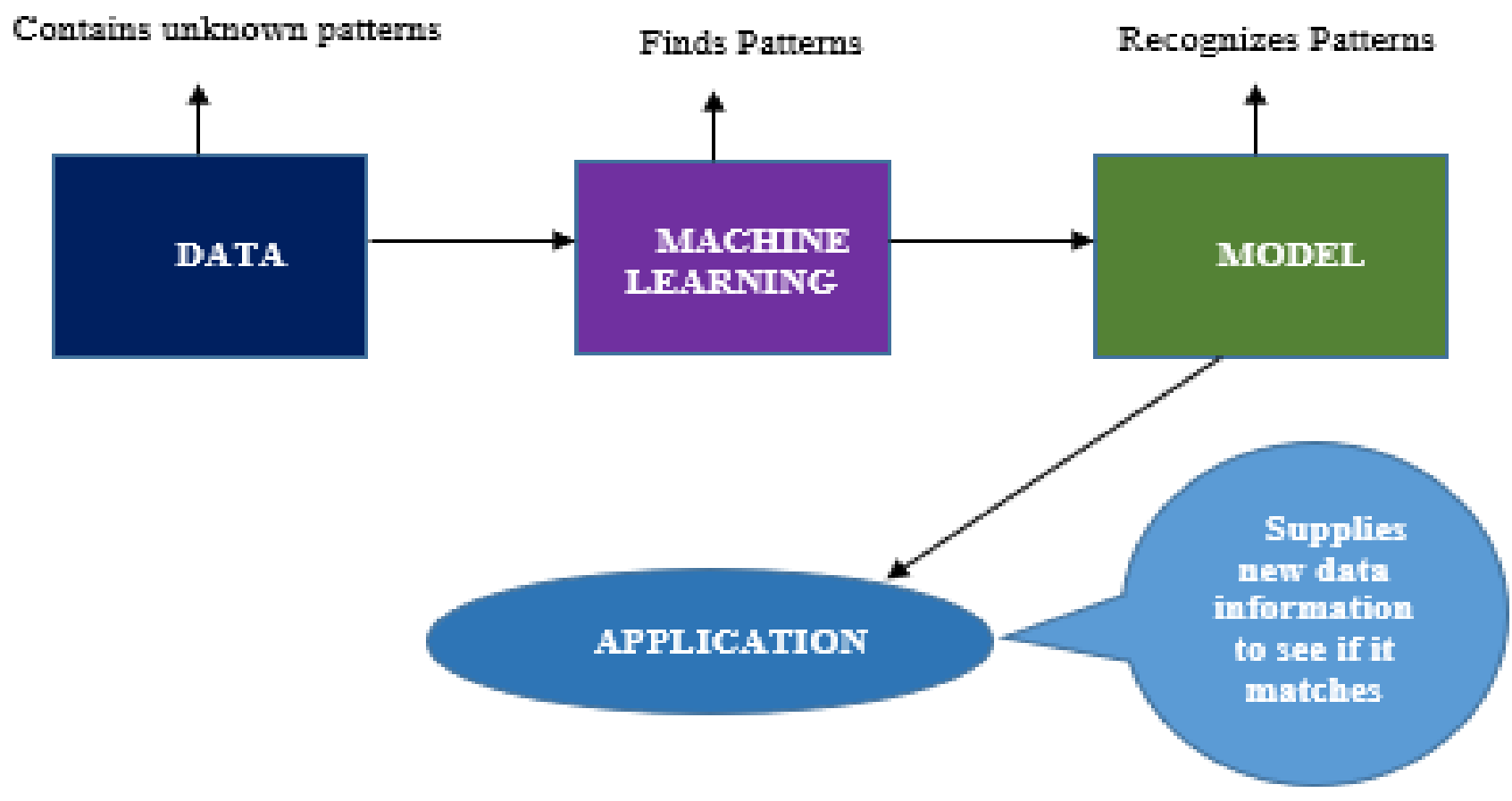

Fig. 5. Machine-learning Patterns through sensor fusion.

\section{Discussion and Conclusion}

A methodology for intelligent monitoring using multi-sensor fusion for a crude distillation column was presented. The method explained the technique using simple input and output information and observing information. The idea was to provide a control solution using a binary matrix to predict trends in order to create an accurate monitoring system.

Focusing on risk assessment methods applied to a distillation column helped with the identification of trends and some regions where the likelihood of malfunctions may be growing. The history of malfunctions was studied and future work may simulate column malfunctions to assist operators and engineers. Using combined hazard-modelling techniques to model risk threat to a crude oil distillation column during operational disturbances could help to systematically make suitable decisions. That could help to improve design regulations and identify potential hazards, eventually leading to safe operation.

Table 1 identified the failure mode and effect analysis technique used. It was integrated into a practical example using 50 years of historical data (Table 2). FTA was introduced. Bow-tie analysis (Fig. 2) demonstrated how two-hazard analysis techniques could be combined to create a more robust risk identification technique to improve fault detection and data reliability, and eliminate any previous improper datasets.

Multi-sensor fusion improved observability by broadening the baseline of physical observable and this could result in significant improvements. The use of a single sensor might not be effective in creating an intelligent monitoring system. With the complexity of combining sensors to create a learning algorithm, it is easy for a data set to be mismatched. Multiple sensor fusion could help to establish a pattern from independent sensors though to form a systemic way of thinking. This method helped in improving pattern recognition which could be implemented into machine learning. That could be used to detect or predict anomalies, predict faults and possibly predict catastrophes.

A limitation was a concern with the accuracy and reliability improvements. Future work will investigate phase changes and material balance on sensor fusion performance and the data will be fed into some intelligent control systems that have recently been used to control powered wheelchairs [24-28]. It will also be used with decision-making systems [29-31] and decisionmaking algorithms that are currently being investigated [32-40]. 


\section{References}

1. J. Bartok, O. Habala, P. Bednar, M. Gazak, L. Hluchý. Data mining and integration for predicting significant meteorological phenomena. Procedia Comput. Sci., 1: 37-46, 2010.

2. C.D. Chang, C.C. Wang, C.B. Jiang. Using Data Mining Techniques for Multi-Diseases Prediction Modeling of Hypertension and Hyperlipidemia by Common Risk Factors. Expert Systems with Applications, In Press, Accepted Manuscript. 2010.

3. C. Mabrouki, F. Bentaleb and A. Mousrij. A decision support methodology for risk management within a port terminal. Safety Science, 63, pp.124-132. 2014.

4. P. Slovic, M.L. Finucane, E. Peters and D.G. MacGregor. Risk as analysis and risk as feelings: Some thoughts about affect, reason, risk, and rationality. Risk analysis, 24(2), pp.311-322. 2004.

5. Y. Deng, R. Sadiq, W. Jiang and S. Tesfamariam. Risk analysis in a linguistic environment: a fuzzy evidential reasoning-based approach. Expert Systems with Applications, 38(12), pp.15438-15446. 2011.

6. K. Mokhtari, J. Ren, C. Roberts and J. Wang. Decision support framework for risk management on sea ports and terminals using fuzzy set theory and evidential reasoning approach. Expert Systems with Applications, 39(5), pp.5087-5103. 2012.

7. H. Durrant-Whyte. Sensor Models and Multisensor Integration. The International Journal Of Robotics Research, 7(6), 97-113. doi: $10.1177 / 027836498800700608,1988$.

8. S.D. Mohaghegh. A new methodology for the identification of best practices in the oil and gas industry, using intelligent systems. J. Petrol. Sci. Eng., 49: 239-260, 2005.

9. E. Hajizadeh, A.H. Davari, J. Shahrabi. Application of data mining techniques in stock markets: A survey, J. Econ. Int. Finance 2(7): 109-118, 2010.

10. B. Khaleghi, A. Khamis, F. Karray. and S. Razavi. Multisensor data fusion: A review of the state-of-the-art. Information Fusion, 14(1), pp.28-44, 2013.

11. F. Ikwan. Reducing energy losses and alleviating risk in petroleum engineering using decision making and alarm systems "Journal of computing in systems and engineering" ISSN 1472-9083, 422-429, 2018.

12. S. Mandal and J. Maiti. Risk analysis using FMEA: Fuzzy similarity value and possibility theory based approach. Expert Systems with Applications, 41(7), pp.3527-3537. 2014.

13. R. Luo and M. Kay. Multisensor integration and fusion in intelligent systems. IEEE Transactions on Systems, Man, And Cybernetics, 19(5), 901-931. doi: 10.1109/21.44007, 1989.

14. R. Riahi, I. Robertson, S. Bonsall, I. Jenkinson and J. Wang. A proposed methodology for assessing the reduction of a seafarer's performance with insufficient recuperative rest. Journal of Marine Engineering \& Technology, 12(2), pp.11-28. 2013.

15. S. M. M Lavasani. “Advanced Quantitative Risk Assessment of Offshore Gas Pipeline Systems” PhD Thesis, School of Engineering and Maritime Operations, Liverpool John Moores University, UK. (2010).

16. R. Ferdous, F. Khan, R. Sadiq, P. Amyotte, B. Veitch. Handling data uncertainties in event tree analysis. Process safety and environmental protection. 2009 Sep 30; 87(5):283-92.

17. M.R. Saybani, Teh Ying WAL. Applied Data Mining Approach in Ubiquitous World of Air Transportation. In: Comput. Sci. Convergence Info. Technol., ICCIT '09. Fourth Int. Conf., pp. 1218- 1222, 2009.

18. L.A Klein. Sensor and Data Fusion Concepts and Applications (second ed.), Society of Photo-optical Instrumentation Engineers (SPIE), Bellingham, WA, 1999.

19. P.O Omoarebun. Disaster risk reduction in petroleum engineering. Journal of Computing in Systems and Engineering. ISSN 14729083, 2018.

20. F.E.White. Data Fusion Lexicon, Joint Directors of Laboratories, Technical Panel for C3, Data Fusion Sub-Panel, Naval Ocean Systems Center, San Diego, 1991.

21. P. Smets. Analyzing the combination of conflicting belief functions Information Fusion, 8 (4) pp. 387-412, 2007.

22. G. Selim, S. Seker. Signal based approach for data mining in fault detection of induction motor', Sci. Res. Essays 6(22): 4720-4731, , 2011.

23. Saybani MR, Teh Ying. Applied Data Mining Approach in Ubiquitous World of Air Transportation. In: Comput. Sci. Convergence Info. Technol., ICCIT '09. 4th Int. Conf., pp. 1218- 1222, WAL 2009.

24. Sanders D, Gegov A, Ndzi D. Knowledge-based expert system using a set of rules to assist a tele-operated mobile robot, in Studies in Computational Intelligence, (eds) Y. Bi, S. Kapoor, and R. Bhatia, 2018, 751, Springer, 2018b, pp. 371-392.

25. Sanders D, Sanders H, Gegov A, Ndzi D. Rule-based system to assist a tele-operator with driving a mobile robot. Lecture Notes in Networks and Systems, 16, Springer, pp. 599-615, 2018.

26. Sanders D, Okonor OM, Langner M, Hassan Sayed M, Khaustov SA, Omoarebun P. Using a simple expert system to assist a powered wheelchair user. in Y Bi, R Bhatia \& S Kapoor (eds), Advances in Intelligent Systems and Computing, vol. 1037, Springer, pp. 662379.

27. Gegov, A., Gobalakrishnan, N.and Sanders, D. A.: Rule base compression in fuzzy systems by filtration of non-monotonic rules, Journal of Intelligent \& Fuzzy Systems, 27(4), 2029-2043, (2014).

28. Sanders D, Gegov A, Haddad M, Ikwan F, Wiltshire D, Tan YC. A Rule-based Expert System to decide on direction and speed of a powered wheelchair. IEEE Proceedings of the SAI Conference on IntelliSys. London, U.K., 2018a, pp. 426 - 433. 
29. Sanders D, Gegov A, Haddad M, Ikwan F, Wiltshire D, Tan YC. A rule-based expert system to decide on direction and speed of a powered wheelchair. in K Arai, S Kapoor \& R Bhatia (eds), Advances in Intelligent Systems and Computing, vol. 868, Springer, pp. 822-838.

30. Sanders D. Recognizing shipbuilding parts using artificial neural networks and Fourier descriptors, Proceedings of the Institution of Mechanical Engineers - Part B- Journal of Engineering Manufacture, 223(3), 337-342, (2009)a.

31. Sanders D. Using self-reliance factors to decide how to share control between human powered wheelchair drivers and ultrasonic sensors, IEEE Transactions on Neural Systems and Rehabilitation Engineering, 25(8), 1221-1229, (2017).

32. Haddad M, Sanders D, Bausch N, TewkesburyvvG, Gegov A, Hassan Sayed M. Learning to make intelligent decisions using an Expert System for the intelligent selection of either PROMETHEE II or the Analytical Hierarchy Process. in K Arai, S Kapoor \& R Bhatia (eds), Advances in Intelligent Systems and Computing, vol. 868, Springer, pp. 1303-1316.

33. Haddad MJM, Sanders D, Gegov A, Hassan Sayed M, Huang Y, Al-Mosawi M. Combining multiple criteria decision making with vector manipulation to decide on the direction for a powered wheelchair. in Y Bi, R Bhatia \& S Kapoor (eds), Advances in Intelligent Systems and Computing, vol. 1037, Springer, pp. 680-693, .

34. Haddad MJM, Sanders D, Tewkesbury G, Gegov A, Hassan Sayed M, Ikwan F. Initial results from using Preference Ranking Organization METHods for Enrichment of Evaluations to help steer a powered wheelchair. in Y Bi, R Bhatia \& S Kapoor (eds), Advances in Intelligent Systems and Computing, vol. 1037, Springer, pp. 648-661.

35. Sanders D, Robinson DC, Hassan Sayed M, Haddad MJM, Gegov A, Ahmed N. Making decisions about saving energy in compressed air systems using Ambient Intelligence and Artificial Intelligence. in K Arai, S Kapoor \& R Bhatia (eds), Advances in Intelligent Systems and Computing, vol. 869, Springer, pp. 1229-1236.

36. Haddad M, Sanders D, Bausch N. Selecting a Robust Decision Making Method to Evaluate Employee Performance, International Journal of Management and Decision Making. 8(4),333 -351, (2019).

37. Haddad M, Sanders D. The Behavior of Three Discrete Multiple Criteria Decision Making Methods in the Presence of Uncertainty, Operations Research Perspectives, to be published.

38. Haddad MJM, Sanders D, Bausch N. Selecting a robust decision making method to evaluate employee performance, International Journal of Management and Decision Making, vol. 18, no. 4, pp. 333-351.

39. Haddad MJM, Sanders D. Selecting a best compromise direction for a powered wheelchair using PROMETHEE, IEEE Transactions on Neural Systems and Rehabilitation Engineering, vol. 27, no. 2, pp. 228-235. https://doi.org/10.1109/TNSRE.2019.2892587

40. Sanders D, Robinson DC, Hassan Sayed M, Haddad MJM, Gegov A, Ahmed N. Making decisions about saving energy in compressed air systems using Ambient Intelligence and Artificial Intelligence. in K Arai, S Kapoor \& R Bhatia (eds), Advances in Intelligent Systems and Computing, vol. 869, Springer, pp. 1229-1236. 